\title{
Strategi Peningkatan Partisipasi Perempuan dalam Kegiatan Penyuluhan Pertanian di Subak Sembung Kota Denpasar
}

\author{
NI MADE DWI SUTRA PRAMASANTI, \\ NI WAYAN SRI ASTITI, DAN I MADE SARJANA
}

\author{
Program Studi Agribisnis, Fakultas Pertanian, Universitas Udayana \\ Jalan PB. Sudirman 80232 Denpasar \\ E-mail: nimadedwisutrapramasanti@yahoo.co.id \\ wayansriastiti@yahoo.co.id
}

\section{Abstract \\ Strategy for Increasing Women's Participation in Agricultural Extension Activities in Subak Sembung of Denpasar City}

The study aims to determine alternative strategies to increase women's participation in agricultural extension activities in Subak Sembung of Denpasar City. This study aims to identify how the stengths, weakness, opportunities, and threats of increasing the participation of woman in agricultural extension activities in Subak Sembung of Denpasar City, viewed from the internal environment aspect to investigate the strengths and weaknesses, and the external aspects to find out the opportunities and threats. The research location was in Subak Sembung, Peguyangan Village of Denpasar City, Bali Province. Respondents in this study were sixty-five people. Respondents were determined by purposive sampling to investigate the internal and external environmental factors of women in Subak Sembung of Denpasar City. This study used three analyzes: internal environment analysis, external environmental analysis, and SWOT analysis (strengths, weakness, opportunities, and threats). Women's participation in the Subak Sembung of Denpasar City has been able to utilize their stengths to overcome the weakness and participation of women in Subak Sembung is able to take advantage of opportunities to overcome the threats. There are ten alternative of strategies: SO strategy, one of which is to sell goods that are needed by the market and contain high economic value. WO strategy they continuously learn through interesting material and extension method and have big business opportunities. ST strategy, it involves women in extension activities in order to have responsibilities and to share time for family and extension activities, and WT strategy is to make more efficient and modern agricultural extension (untilizing digital media) that can be seen anytime and anywhere without disturbing other important activities.

Keywords: women, alternative strategies, internal environment, external environment

\section{Pendahuluan}

\subsection{Latar Belakang}

Penyuluhan pertanian adalah sistem pendidikan luar sekolah di bidang pertanian untuk petani, nelayan, keluarganya serta anggota masyarakat pertanian. Berhasil tidaknya program penyuluhan pertanian tidak hanya tergantung dari pemerintah juga penyuluh, tetapi sebagian besar ditentukan oleh peranan petani beserta keluarganya 
yang merupakan pelaku langsung dalam produksi hasil pertanian. Peran perempuan dalam kegiatan penyuluhan pertanian saat ini masih rendah. Banyak faktor penyebabnya, diantaranya kurangnya akses dan peluang yang diperoleh, kesibukan di dalam mengurus rumah tangga dan mengikuti kegiatan sosial atau keagamaan, pengetahuan yang memadai terkait kegiatan penyuluhan itu sendiri, materi dan metode penyuluhan yang tidak tepat sasaran dan lain sebagainya (Indah, 2011). Peran perempuan masih rendah dalam mengikuti kegiatan penyuluhan pertanian dengan berbagai macam alasan. Perlu adanya penyadaran bagi kita semua bahwa penyuluhan pertanian sangatlah penting bagi perempuan maupun bagi laki-laki. Melalui kegiatan penyuluhan dapat menambah wawasan dari petani maupun non petani yang ingin mengetahui perbaruan teknologi di bidang pertanian yang semakin modern. Perlu diketahui faktor internal dan eksternal petani perempuan serta mengetahui strategi peningkatan pasrtisipasi perempuan berdasarkan strategi alternatif. Sebagai bahan acuan dan pembelajaran bagi perempuan lain dan peningkatan partisipasi dan pelaksaanan kegiatan penyuluhan pertanian sehingga bisa berkembang dan sukses baik untuk saat ini maupun untuk masa yang akan datang.

\subsection{Tujuan}

Tujuan penelitian ini adalah mengetahui faktor internal dan faktor eksternal peningkatan partisipasi perempuan dalam kegiatan penyuluhan pertanian serta mengetahui strategi alternatif yang dapat digunakan untuk meningkatkan partisipasi perempuan dalam kegiatan penyuluhan pertanian.

\section{Metode Penelitian}

\subsection{Lokasi dan Waktu Penelitian}

Penelitian ini akan dilaksanakan di Subak Sembung, Kota Denpasar. Penentuan lokasi penelitian dipilih secara purposive yaitu pemilihan lokasi yang dilaksanakan secara sengaja. Penelitian dilaksanakan selama sembilan bulan yakni dari bulan April sampai Desember 2017. Dasar pertimbangannya; (1) Subak Sembung merupakan subak berprestasi sering memperoleh penghargaan dari tingkat daerah sampai tingkat provinsi. Contohnya mendapat juara I lomba subak di tingkat Provinsi Bali pada tahun 2014 dan petani wanita di Subak Sembung mendapat penghargaan pemenang Lomba Memasak Beras Merah yang memenangkan Juara I pada tahun 2006, (2) Terdapat kelompokkelompok tani yang terbagi dalam beberapa bagian sesuai dengan hasil pertanian yang terdapat di Subak Sembung, dan beberapa kelompok diataranya melibatkan petani perempuan untuk turut serta aktif dalam kelompok, dan (3) Perempuan atau petani perempuan di Subak Sembung masih aktif, maju dan berhasil tanpa mengemal perbedaan usia dan gender dibandingkan perempuan di subak lainnya dalam melaksanakan kegiatan pertanian ataupun perlombaan yang diadakan sehingga mendapatkan juara.

\subsection{Jenis dan Sumber Data}

Jenis data yang digunakan dalam penelitian ini berupa data kualitatif dan kuantitatif. Data kualitatif ini berbentuk kata, penjelasan, skema, dan gambaran yang tidak dapat dihitung (Sugiyono, 2014). Data kualitatif dalam penelitian ini meliputi hasil pengamatan langsung di lapangan berupa gambaran umum lokasi penelitian, hasil dari wawancara, informasi yang berkaitan dengan strategi peningkatan partisipasi perempuan dalam kegiatan penyuluhan pertanian, serta data eksternal dan internal yang 
mendukung atau mampu meningkatkan partisipasi perempuan dalam kegiatan penyuluhan pertanian. Data kuantitatif adalah data yang dapat dihitung dan dalam bentuk angka-angka dengan satuan tertentu (Sugiyono, 2014). Data kuantitatif yang dicari dalam penelitian ini adalah jumlah anggota petani wanita yang aktif, nama responden, umur responden, pendidikan responden, dan data jumlah anggota keluarga.

Sumber data yang digunakan dalam penelitian ini yakni data primer dan data sekunder. Data primer adalah sumber data yang diperoleh secara langsung dari sumber aslinya (Maulidi, 2016). Data primer dalam penelitian yang dikumpulkan berupa karakteristik responden, kekuatan, kelemahan, peluang, dan ancaman dalam melakukan kegiatan penyuluhan pertanian. Wawancara dilakukan kepada responden di Subak Sembung. Data sekunder adalah sumber data penelitian yang diperoleh melalui media perantara atau secara tidak langsung (Maulidi, 2016). Data sekunder dalam penelitian diperoleh dari Dinas Pertanian Perkebunan dan Perhutanan Kota Denpasar, BPS, penyuluh, atau PPL di Subak Sembung dan hasil penelitian sebelumnya yang terkait dengan penelititan, buku-buku, dan internet yang menunjang dalam penelitian ini.

\subsection{Metode Pengumpulan Data}

Data faktor lingkungan internal dan faktor lingkungan eksternal perempuan di Subak Sembung, Kota Denpasar dikumpulkan melalui observasi, yang merupakan teknik pengumpulan data yang mempunyai ciri yang spesifik bila dibandingkan dengan teknik lainnya (Sugiyono, 2009) melakukan wawancara, bertanya langsung kepada responden, dan sumber informasi lainnya dengan menggunakan daftar pertanyaan (kuisoner) yang telah disiapkan sebelumnya (Singarimbun dan Effendi, 1989). Studi dokumentasi yang bertujuan untuk mendukung dan memberi ketegasan hasil observasi dan wawancara dalam penelitian kualitatif maupun kuantitatif.

\subsection{Populasi dan Sampel}

Populasi dalam penelitian ini adalah istri-istri petani anggota Subak Sembung yang berjumlah 189 orang yang dikelompokkan berdasarkan enam munduk. Penentuan sampel yang dijadikan objek penelitian ditentukan dengan menggunakan rumus Slovin. Berdasarkan rumus tersebut dapat disimpulkan bahwa sampel yang digunakan dalam penelitian ini sebanyak 65,4. Penelitian tidak memungkinkan menggunakan orang dalam jumlah pecahan, sehingga sampel dibulatkan menjadi 65 orang. Teknik sampling yang digunakan berupa propotional random sampling yang merupakan pengambilan sampel secara proposi yang dilakukan dengan mengambil subjek dari setiap strata atau setiap wilayah ditentukan seimbang dengan banyaknya subjek dalam masing-masing strata atau wilayah (Arikunto, 2006).

\subsection{Instrumen Penelitian}

Insrumen penelitian merupakan alat yang dipakai dalam sebuah penelitian. Sugiyono (2016) mengatakan instrumen penelitian adalah suatu alat yang digunakan untuk mengukur fenomena alam atau sosial yang diamati. Penelitian ini menggunakan instrumen penelitian berupa kuisioner yang ditujukan kepada seluruh responden.

\subsection{Pengujian Instrumen Penelitian}

Penelitian ini mengguakan variabel-variabel sosial yang diukur secara kualitatif. Variabel tersebut disusun oleh peneliti sehingga perlu diuji. Pengujian variabel penelitian dalam kuisioner dilakukan dengan uji validitas dan reabilitas. Menurut 
Sarjono dan Julianita (2011), uji validitas adalah bukti bahwa instrument, teknik atau proses yang digunakan untuk mengukur konsep yang dimaksudkan. Uji reliabilitas menunjukkan sejauh mana pengukuran tanpa bias (bebas kesalahan) sehingga dapat menjamin pengukuran konsisten lintas waktu, atau konsisten jika dilakukan dua kali atau lebih pengukuran. Pengujian validitas dan reabilitas dilakukan dengan menggunakan software SPSS.

\subsection{Metode Analisis Data}

Metode analisis data yang digunakan dalam penelitian ini adalah analisis deskriptif kualitatif. Penelitian diawali dengan menggali dan menentukan kekuatan, kelemahan, ancaman dan peluang yang dimiliki oleh perempuan atau istri para petani di Subak Sembung. Penelitian dinalisis menggunakan analisis lingkungan internal, lingkungan eksternal, matriks IE dan matriks SWOT. Analisis data internal meliputi penilaian terhadap faktor kekuatan (strength) dan kelemahan (weakness), sedangkan analisis eksternal meliputi penilaian terhadap faktor peluang (opportunity) dan ancaman (threats). Data yang diperoleh selanjutnya diolah dan ditabulasikan ke dalam bentuk tabel dan dihitung frekuensi serta presentasinya dengan bantuan skoring menggunakan skala ordinal (likert). Rentang keberhasilan akan dihitung dengan skor 1, 2, dan 3.

\section{Hasil dan Pembahasan}

\subsection{Identifikasi Faktor Internal dan Faktor Eksternal 3.1.1 Identifikasi faktor internal}

Menurut Reksodipardjo (1992) faktor lingkungan internal adalah faktor yang berasal di dalam perempuan atau petani perempuan di Subak Sembung Kota Denpasar yang bersifat positif. Berdasarkan hasil identifikasi lingkungan internal maka dapat diketaui daktor-faktor kekuatan dan kelemahan yang ada di dalam perempuan. Adapun faktor lingkungan internal perempuan di Subak Sembung Kota Denpasar adalah sebagai berikut.

1. Faktor internal kekuatan, yaitu; (a) semangat (antusiasme) perempuan dalam mengikuti kegiatan penyuluhan pertanian, (b) keinginan perempuan meningkatkan wawasan dan pengetahuan dibidang pertanian, (c) intensitas atau jumlah waktu yang dialokasikan perempuan dalam mengikuti kegiatan penyuluhan pertanian, (d) mampu menerapkan inovasi baru dari penyuluh, (e) ketersediaan tempat dan fasilitas lainnya untuk mengadakan penyuluhan pertanian bagi perempuan, dan (f) tekad yang kuat dari perempuan untuk memperoleh penghasilan lebih untuk keluarga.

2. Faktor internal kelemahan, yaitu; (a) umumnya tingkat pendidikan petani perempuan masih rendah, (b) persepsi negatif petani perempuan menyatakan mengikuti penyuluhan pertanian tidak penting, (c) kesibukan perempuan dalam menyiapkan dan melaksanakan upacara keagamaan di tingkat keluarga dan komunitas, dan (d) terbatasnya akses perempuan terhadap kegiatan penyuluhan pertanian.

\subsubsection{Identifikasi faktor eksternal}

Faktor lingkungan eksternal adalah faktor berada diluar perempuan atau petani perempuan yang bersifat negatif dapat mempengaruhi perempuan tersebut. Berdasarkan hasil identifikasi lingkungan eksternal maka dapat diketahui faktor-faktor peluang dan ancaman yang ada di dalam perempuan. Adapun faktor lingkungan eksternal perempuan di Subak Sembung Kota Denpasar adalah sebagai berikut. 
1. Faktor eksternal peluang, yaitu; (a) adanya program kerja pemerintah yang ditujukan untuk pemeberdayaan petani perempuan, (b) adanya peluang bisnis berbasis produk pertanian lokal yang semakin terbuka, (c) adanya peningkatan kualitas produk pertanian yang diikuti peningkatan harga sehingga peluang mendapatkan keuntungan semakin tinggi, dan (d) adanya tenaga penyuluh pertanian perempuan yang dapat menjadi inspirator atau motivator keterlibatan perempuan di sektor pertanian.

2. Faktor eksternal ancaman, yaitu; (a) adanya peluang kerja dibidang non pertanian memberikan hasil yang pasti, (b) adanya persepsi masyarakat bahwa perempuan harus fokus mengerjakan pekerjaan domestik dirumah dan suami yang bekerja untuk menghidupi keluarga, dan (c) adanya tenaga kerja luar Bali yang bersedia mengerjakan pekerjaan disektor pertanian.

\subsection{Strategi Peningkatan Partisipasi Perempuan dalam Kegiatan Penyuluhan Paertanian}

\subsubsection{Hasil evaluasi faktor internal}

Berdasarkan hasil dari penyebaran kuisoner yang telah dilakukan, maka dapat diketahui bobot dan rating serta skor dari masing-masing faktor. Berikut adalah hasil perhitungan matriks IFAS yang dapat dilihat pada Tabel 1 di bawah ini.

\section{Tabel 1.}

Perhitungan Matriks Evaluasi Faktor Internal Strategi Peningkatan Partisipasi Perempuan dalam Kegiatan Penyuluhan Pertanian di Subak Sembung

Kota Denpasar

\begin{tabular}{|c|c|c|c|c|}
\hline No & Kekuatan & Bobot & Rating & Skor \\
\hline 1 & $\begin{array}{l}\text { Semangat (antusiasme) perempuan dalam mengikuti kegiatan penyuluhan } \\
\text { pertanian }\end{array}$ & 0,102 & 4 & 0,408 \\
\hline 2 & $\begin{array}{l}\text { Keinginan perempuan meningkatkan wawasan dan pengetahuan dibidang } \\
\text { pertanian }\end{array}$ & 0,101 & 4 & 0,404 \\
\hline 3 & $\begin{array}{l}\text { Intensitas atau jumlah waktu yang dialokasikan perempuan dalam } \\
\text { mengikuti kegiatan penyuluhan pertanian }\end{array}$ & 0,099 & 3 & 0,279 \\
\hline 4 & Mampu menerapkan inovasi baru dari penyuluh & 0,099 & 4 & 0,396 \\
\hline 5 & $\begin{array}{l}\text { Ketersediaan tempat dan fasilitas lainnya untuk mengadakan penyuluhan } \\
\text { pertanian bagi perempuan }\end{array}$ & 0,096 & 3 & 0,288 \\
\hline \multirow[t]{3}{*}{6} & $\begin{array}{l}\text { Tekad yang kuat dari perempuan untuk memperoleh penghasilan lebih } \\
\text { untuk keluarga }\end{array}$ & 0,102 & 4 & 0,408 \\
\hline & Total Bobot Kekuatan & 0,572 & & 0,996 \\
\hline & Kelemahan & & & \\
\hline 1 & Umumnya tingkat pendidikan petani perempuan masih rendah & 0,098 & 3 & 0,294 \\
\hline 2 & $\begin{array}{l}\text { Persepsi negatif petani perempuan menyatakan mengikuti penyuluhan } \\
\text { pertanian tidak penting }\end{array}$ & 0,095 & 3 & 0,285 \\
\hline 3 & $\begin{array}{l}\text { Kesibukan perempuan dalam menyiapkan dan melaksanakan upacara } \\
\text { keagamaan di tingkat keluarga dan komunitas }\end{array}$ & 0,102 & 4 & 0,408 \\
\hline \multirow[t]{3}{*}{4} & Terbatasnya akses perempuan terhadap kegiatan penyuluhan pertanian & 0,100 & 3 & 0,300 \\
\hline & Total Bobot Kelemahan & 0,400 & & 1,287 \\
\hline & Total Kekuatan + Kelemahan & 1 & 35 & 3,488 \\
\hline
\end{tabular}

Sumber : Analisis data primer

Pada Tabel 1 diketahui bahwa total keseluruhan faktor internal jumlahnya adalah 1 yang menandakan hasil perhitungan tersebut benar. Total skor untuk faktor kekuatan sebesar 2,201 sedangkan total skor untuk faktor kelemahan sebesar 1,287. Hasil ini menunjukkan bahwa partisipasi perempuan dalam kegiatan penyuluhan pertanian di 
Subak Sembung Kota Denpasar memiliki faktor kekuatan yang lebih besar dibandingkan dengan faktor kelemahan, berarti partisipasi perempuan tersebut dapat memanfaatkan faktor kekuatan untuk mengatasi kelemahan.

Kekuatan utama bagi partisipasi perempuan dalam kegiatan penyuluhan pertanian di Subak Sembung Kota Denpasar adalah semangat (antusiasme) perempuan dalam mengikuti kegiatan penyuluhan pertanian, dan tekad yang kuat dari perempuan untuk memperoleh penghasilan lebih untuk keluarga dengan skor sama yaitu 0,408 yang memiliki pengaruh besar dan menjadi faktor kekuatan pada partisipasi perempuan dalam kegiatan penyuluhan pertanian di Subak Sembung Kota Denpasar. Kelemahan utama bagi partisipasi perempuan dalam kegiatan penyuluhan pertanian di Subak Sembung Kota Denpasar adalah kesibukan perempuan dalam menyiapkan dan melaksanakan kegiatan keagamaan ditingkat keluarga dan komunitas dengan skor 0,408. Parameter ini memiliki pengaruh besar dan menjadi faktor kelemahan bagi partisipasi perempuan dalam kegiatan penyuluhan pertanian di Subak Sembung Kota Denpasar. Keseluruhan hasil analisis faktor eksternal berupa peluang dan ancaman ini mendapat jumlah skor sebesar 3,488 dan dibulatkan menjadi 3,5. Hasil tersebut menunjukkan bahwa faktor internal partisipasi perempuan dalam kegiatan Penyuluhan pertanian di Subak Sembung Kota Denpasar memiliki kondisi internal sangat kuat. Faktor kekuatan tersebut dapat digunakan untuk mengatasi kelemahan.

\subsubsection{Hasil evaluasi faktor eksternal}

Berdasarkan hasil dari penyebaran kuisoner yang telah dilakukan, maka dapat diketahui bobot dan rating serta skor dari masing-masing faktor. Berikut adalah hasil perhitungan matriks EFAS yang dapat dilihat pada Tabel 2 di bawah ini.

\section{Tabel 2.}

Perhitungan Matriks Evaluasi Faktor Eksternal Strategi Peningkatan Partisipasi Perempuan dalam Kegiatan Penyuluhan Pertanian di Subak Sembung

Kota Denpasar

\begin{tabular}{|c|c|c|c|c|}
\hline No & Peluang & Bobot & Rating & Skor \\
\hline 1 & $\begin{array}{l}\text { Adanya program kerja pemerintah yang ditujukan untuk pemeberdayaan } \\
\text { petani perempuan }\end{array}$ & 0,147 & 2 & 0,294 \\
\hline 2 & $\begin{array}{l}\text { Adanya peluang bisnis berbasis produk pertanian lokal yang semakin } \\
\text { terbuka }\end{array}$ & 0,142 & 2 & 0,284 \\
\hline 3 & $\begin{array}{l}\text { Adanya peningkatan kualitas produk pertanian yang diikuti peningkatan } \\
\text { harga sehingga peluang mendapatkan keuntungan semakin tinggi }\end{array}$ & 0,148 & 1 & 0,148 \\
\hline \multirow[t]{3}{*}{4} & $\begin{array}{l}\text { Adanya tenaga penyuluh pertanian perempuan yang dapat menjadi } \\
\text { inspirator atau motivator keterlibatan perempuan di sektor pertanian }\end{array}$ & 0,135 & 2 & 0,270 \\
\hline & Total Bobot Peluang & 0,572 & & 0,996 \\
\hline & Ancaman & & & \\
\hline 1 & $\begin{array}{l}\text { Adanya peluang kerja dibidang non pertanian memberikan hasil yang } \\
\text { pasti }\end{array}$ & 0,145 & 1 & 0,145 \\
\hline 2 & $\begin{array}{l}\text { Adanya persepsi masyarakat bahwa perempuan harus fokus } \\
\text { mengerjakan pekerjaan domestik dirumah dan suami yang bekerja untuk } \\
\text { menghidupi keluarga }\end{array}$ & 0,131 & 2 & 0,262 \\
\hline \multirow[t]{3}{*}{3} & $\begin{array}{l}\text { Adanya tenaga kerja luar Bali yang bersedia mengerjakan pekerjaan } \\
\text { disektor pertanian. }\end{array}$ & 0,147 & 1 & 0,147 \\
\hline & Total Bobot Ancaman & 0,423 & & 0,554 \\
\hline & Total Peluang + Ancaman & 1 & 11 & 1,550 \\
\hline
\end{tabular}

Sumber : Analisis data primer 
Berdasarkan Tabel 2 diketahui bahwa total keseluruhan faktor eksternal jumlahnya adalah 1 yang menandakan hasil perhitungan bobot tersebut benar. Total skor untuk faktor peluang sebesar 0,996 sedangkan total skor untuk faktor ancaman sebesar 0,554. Hasil ini menunjukkan bahwa partisipasi perempuan dalam kegiatan penyuluhan pertanian di Subak Sembung Kota Denpasar memiliki faktor peluang yang lebih besar dibandingkan dengan faktor ancaman, berarti partisipasi perempuan tersebut dapat memanfaatkan faktor peluang untuk mengatasi ancaman. Peluang utama bagi partisipasi perempuan dalam kegiatan penyuluhan pertanian di Subak Sembung Kota Denpasar adalah adanya program kerja pemerintah yang ditunjukan untuk pemberdayaan petani perempuan dengan skor yaitu 0,294. Ancaman utama bagi partisipasi perempuan dalam kegiatan penyuluhan pertanian di Subak Sembung Kota Denpasar adalah adanya persepsi masyarakat bahwa perempuan harus fokus mengerjakan pekerjaan domestik dirumah dan suami yang bekerja untuk menghidupi keluarga dengan skor 0,262. Parameter ini memiliki pengaruh besar dan menjadi faktor ancaman bagi partisipasi perempuan dalam kegiatan penyuluhan pertanian di Subak Sembung Kota Denpasar.

Keseluruhan hasil analisis faktor eksternal berupa peluang dan ancaman ini mendapat jumlah skor sebesar 1,550. Hasil ini menunjukkan bahwa faktor eksternal partisipasi perempuan dalam kegiatan penyuluhan pertanian di Subak Sembung Kota Denpasar memiliki kondisi eksternal sangat lemah dibandingkan dengan kondisi internal. Faktor internal lebih mendominasi dibandingkan faktor eksternal terhadap peningkatan pastisipasi perempuan dalam kegiatan penyuluhan pertanian di Subak Sembung Kota Denpasar.

\subsubsection{Analisis matriks internal-eksternal (IE)}

Mengetahui arah dan posisi dari peningkatan partisipasi perempuan dalam kegiatan penyuluhan pertanian di Subak Sembung, maka dapat dilakukan dengan menggunakan analisis matriks Internal-Eksternal (I-E). Analisis matriks I-E menggunakan dua dimensi yaitu hasil perhitungan matriks IFAS (IFE) dan hasil perhitungan matiks EFAS (EFE). Adapun hasil perhitungan matriks I-E terhadap peningkatan partisipasi perempuan dalam kegiatan penyuluhan pertanian di Subak Sembung Kota Denpasar dapat dilihat pada Gambar 1. 


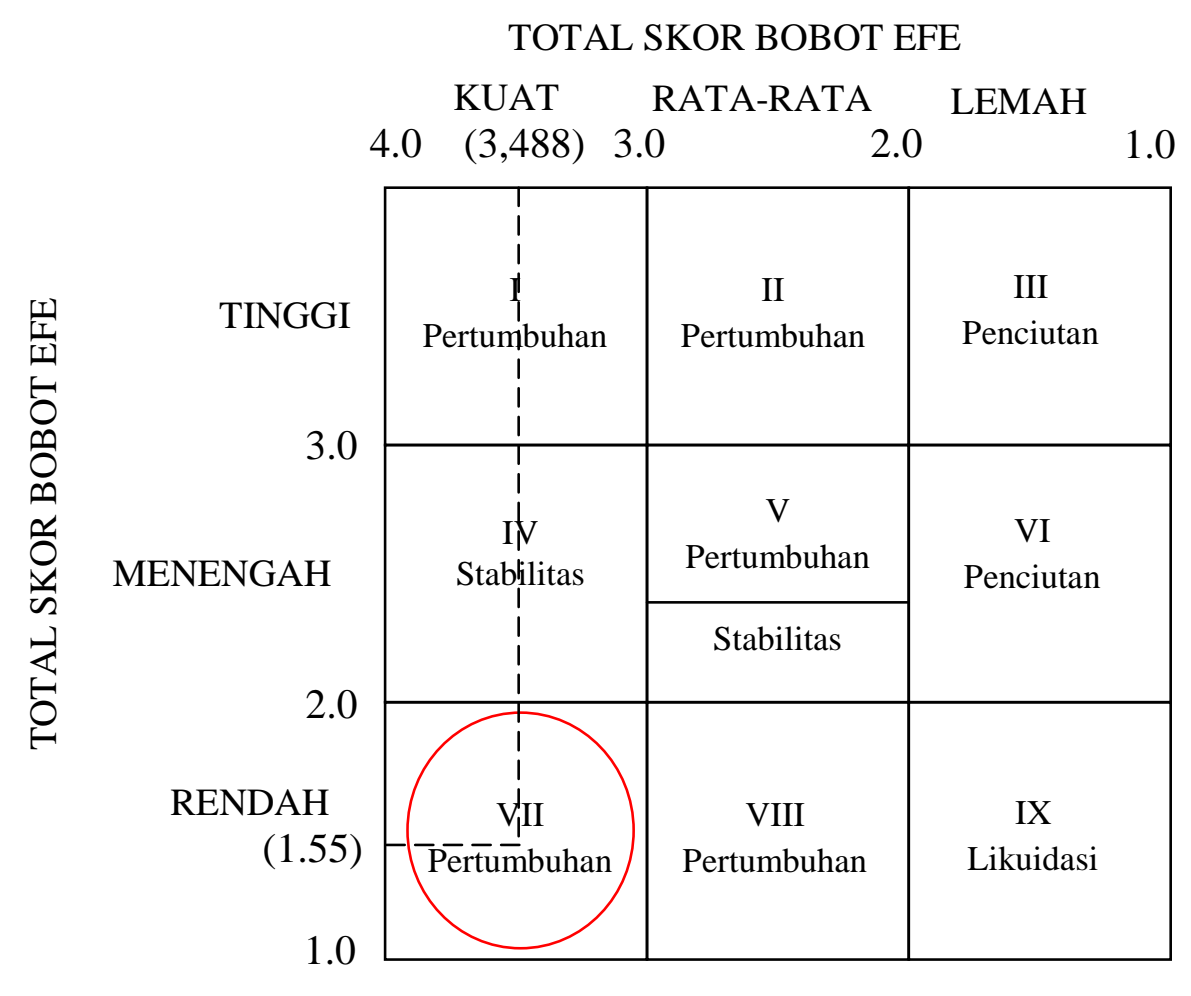

Gambar 1

Matriks Internal-Eksternal (I-E) Strategi Peningkatan Partisipasi Perempuan dalam Kegiatan Penyuluhan Pertanian di Subak Sembung

\section{Kota Denpasar}

Berdasarkan Gambar 1 pemetaan terhadap masing-masing total skor, baik dari faktor internal dan faktor eksternal menggambarkan posisi peningkatan partisipasi perempuan dalam kegiatan penyuluhan pertanian, saat ini berada pada posisi pertumbuhan pada sel VII atau disebut strategi diversifikasi konsentrik dimana pada posisi ini menunjukan bahwa partisipasi faktor internal yang kuat tetapi faktor eksternal yang rendah.

\subsubsection{Analisis Matriks SWOT}

Analisis SWOT merupakan strategi alternatif peningkatan partisipasi perempuan di Subak Sembung Kota Denpasar. Menurut Rangkuti (2016), matriks SWOT menghasilkan empat sel kemungkinan alternatif peningkatan partisipasi perempuan dalam kegiatan penyuluhan pertanian dengan potensi dan kondisi lingkungan internal dan lingkungan eksternal yang dimiliki Perempuan di Subak Sembung Kota Denpasar. Matriks Analisis SWOT perempuan di Subak Sembung Kota Denpasar dapat dilihat pada Tabel 3. 
Tabel 3.

Matriks SWOT

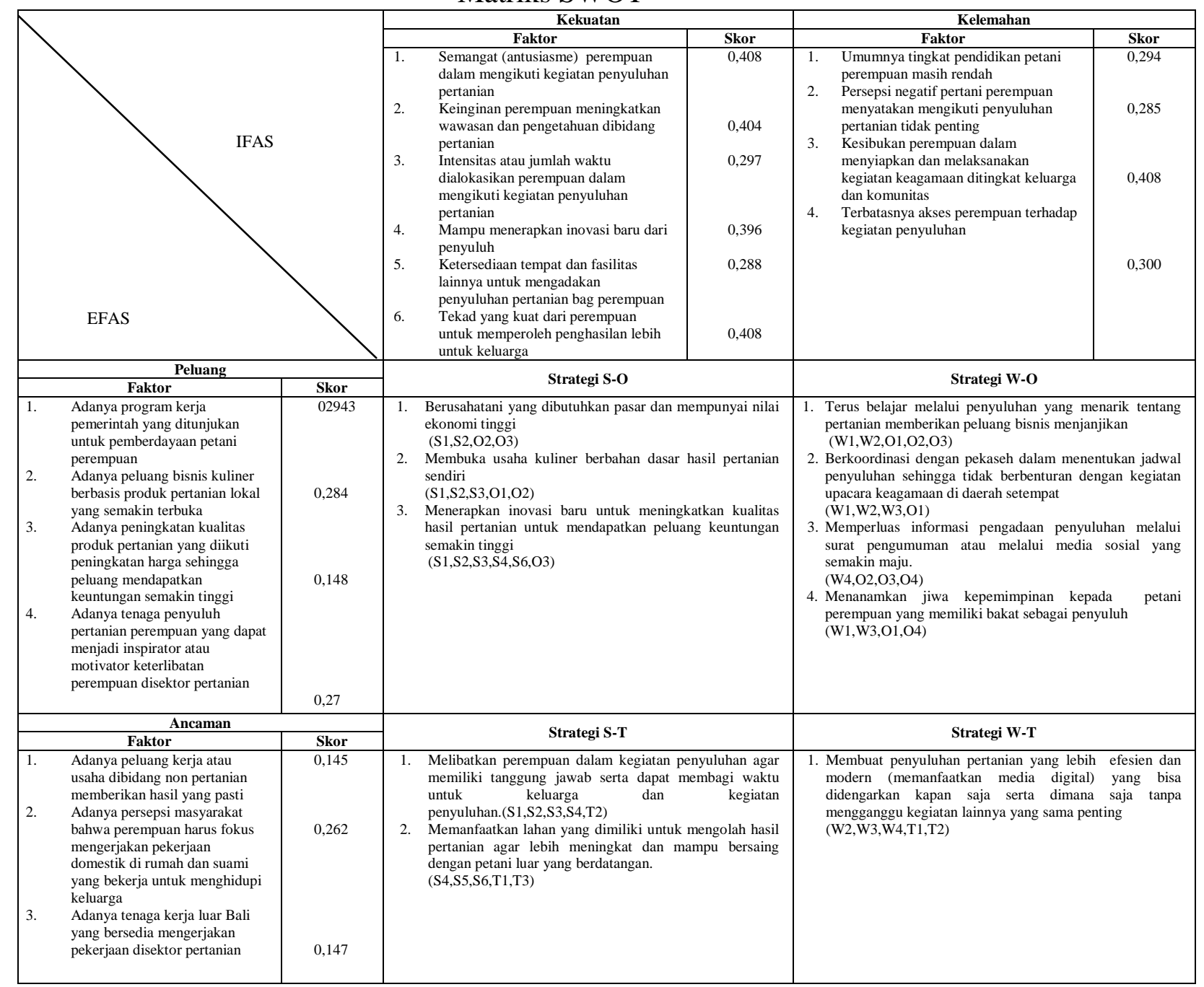

Sumber : Analisis data primer

Berdasarkan Tabel 3 maka dapat dijabarkan alternatif strategi menggunakan analisis SWOT adalah sebagai berikut; (1) Strategi SO (strengths-opportunities), Strategi ini dibuat dengan memanfaatkan seluruh kekuatan untuk merebut dan memanfaatkan peluang sebesar-besarnya. Strategi yang dapat dilakukan adalah berusahatani yang dibutuhkan pasar dan mempunyai nilai ekonomi tinggi, membuka usaha kuliner berbahan dasar hasil pertanian sendiri, dan menerapkan inovasi baru untuk meningkatkan kualitas hasil pertanain untuk mendapatkan peluang keuntungan semakin tinggi, (2) Strategi WO (weakness-opportunities), strategi ini diterapkan berdasarkan pemanfaatan peluang yang ada dengan cara meminimalkan kelemahan. Strategi yang dapat dilakukan adalah terus belajar melalui penyuluhan yang menarik tentang pertanian memberikan peluang bisnis menjanjikan, berkoordinasi dengan pekaseh dalam menentukan jadwal penyuluhan sehingga tidak berbenturan dengan kegiatan upacara keagamaan di daerah setempat, memperluas informasi pengadaan penyuluhan melalui surat pengumuman atau melalui media sosial yang semakin maju, dan menanamkan jiwa kepemimpinan kepada petani perempuan yang memiliki bakat sebagai penyuluh, (3) Strategi ST (stengths-threats), strategi ini dibuat dengan 
menggunakan kekuatan untuk mengatasi ancaman. Strategi yang dapat dilakukan adalah melibatkan perempuan dalam kegiatan penyuluhan agar memiliki tanggung jawab serta dapat membagi waktu untuk keluarga dan kegiatan penyuluhan, memanfaatkan lahan yang dimiliki untuk mengolah hasil pertanian agar lebih meningkat dan mampu bersaing dengan petani luar yang berdatangan, dan (4) Strategi WT (weakness-threats), strategi yang meminimalkan kelemahan yang ada serta menghindari ancaman. Strategi yang dapat dilakukan adalah membuat penyuluhan pertanian yang lebih efesien dan modern (memanfaatkan media digital) yang bisa didengarkan kapan saja serta dimana saja tanpa mengganggu kegiatan lainnya yang sama penting.

\section{Simpulan dan Saran}

\subsection{Simpulan}

Partisipasi perempuan dalam kegiatan penyuluhan di Subak Sembung Kota Denpasar, telah mampu memanfaatkan kekuatan untuk mengatasi kelemahan, serta mampu memanfaatkan peluang untuk mengatasi ancaman. Faktor internal kekuatan tertinggi adalah semangat (antusiasme) perempuan dalam mengikuti kegiatan penyuluhan pertanian dan tekad yang kuat dari perempuan untuk memperoleh penghasilan lebih untuk keluarga. Faktor internal kelemahan tertinggi adalah kesibukan perempuan dalam menyiapkan dan melaksanakan upacara keagamaan di tingkat keluarga dan komunitas. Faktor eksternal peluang tertinggi adalah adanya program kerja pemerintah yang ditujukan untuk pemberdayaan petani perempuan. Faktor tertinggi eksternal ancaman adalah adanya persepsi masyarakat bahwa perempuan harus fokus mengerjakan pekerjaan domestik dirumah dan suami yang bekerja untuk menghidupi keluarga Berdasarkan analisis matriks SWOT diperoleh beberapa alternatif strategi diantaranya a) Strategi SO yaitu berusahatani yang dibutuhkan pasar dan mempunyai nilai ekonomi tinggi, membuka usaha kuliner berbahan dasar hasil pertanian sendiri, dan menerapkan inovasi baru untuk meningkatkan kualitas hasil pertanian untuk mendapatkan peluang keuntungan semakin tinggi, b) Strategi ST yaitu melibatkan perempuan dalam kegiatan penyuluhan agar memiliki tanggung jawab serta dapat membagi waktu untuk keluarga dan kegiatan penyuluhan, serta memanfaatkan lahan yang dimiliki untuk megolah hasil pertanian agar lebih meningkat dan mampu bersaing dengan petani luar yang berdatangan, c) Strategi WO yaitu terus belajar melalui penyuluhan yang menarik tentang pertanian memberikan peluang bisnis menjanjikan, berkoordinasi dengan pekaseh dalam menentukan jadwal penyuluhan sehingga tidak berbenturan dengan kegiatan upacara keagamaan didaerah setempat, memperluas informasi pengadaan penyuluhan melalui surat pengumuman atau melalui media sosial yang semakin maju, dan menanamkan jiwa kepemimpinan kepada petani perempuan yang memiliki bakat sebagai pennyuluh, dan d) Strategi WT yaitu membuat penyuluhan pertanian yang lebih efisien dan modern (memanfaatkan media digital) yang bisa didengarkan kapan saja serta dimana saja tanpa mengganggu kegiatan lainnya yang sama penting.

\subsection{Saran}

Bagi perempuan atau petani perempuan di Subak Sembung Kota Denpasar, penyuluhan dapat diikuti dengan baik dan tetap berjalan sampai nanti adanya penerus yang melanjutkan kegiatan petanian dan penyuluhan yang semakin maju dan modern, karena dengan adanya penyuluhan para perempuan dan petani perempuan dapat meningkatkan ilmu, informasi dan wawasan mereka yang semakin luas agar dapat 
memperoleh hasil pertanian yang semakin meningkat dari inovasi baru serta teknik pemasaran yang diberikan sehingga dapat mensejahterakan keluarga mereka, dan hasil pertanian mereka mampu bersaing dipasaran. Bagi pemerintah diharapkan agar terus menjadi pertimbangan khusus agar terus membantu perempuan atau petani perempuan di Subak Sembung Kota Denpasar dengan memberikan program-program pemberdayaan perempuan yang dapat meningkatkan status, posisi dan kondisi perempuan agar dapat mencapai kemajuan yang setara dengan laki-laki.

\section{Ucapan Terimakasih}

Terimakasih kepada Pekaseh Subak Sembung, staf pengurus Subak Sembung, dan petani perempuan yang telah memberikan informasi terkait penelitian hingga termuat di E-Jurnal.

\section{Daftar Pustaka}

Arikunto, Suharsimi. 2006. Prosedur Penelitian: Suatu Pendekatan Praktik. Rineka Cipta, Jakarta.

Indah, Permatasari. 2011. Skripsi: Faktor-faktor yang Berperan Meningkatkan Partisipasi Perempuan dalam Kegiatan Penyuluhan Pertanian (Kasus pada Kelompok Wanita Tani Suka Makmur di Desa Selanbawak, Kecamatan Marga, Kabupaten Tabanan, Bali). Denpasar.

Maulidi, Achmad. 2016. Pengertian Data Primer dan Data Sekunder. https://www.kanalinfo.web.id/2016/10/pengertian-data-primer-dan- sekunder.html (diakses pada tanggal 18 Januari 2017).

Rangkuti, F. 2016. Analisis SWOT Teknik Membedah Kasus Bisnis. Penerbit PT Gramedia Pustaka Utama, Jakarta.

Reksodipardjo, H. 1992. Manajemen Strategik. Penerbit University Press Gajah Mada, Yogyakarta.

Sarjono, H dan Winda Julianita. 2011. SPSS VS LISREL: Sebuah Pengantar Aplikasi untuk Riset. Salemba Empat. Jakarta.

Sugiyono. 2014. Metode Penelitian Pendidikan Pendekatan Kuantitatif, Kualitatif Dan $R \& D$. Alfabeta. Bandung.

Sugiyono. 2009. Metode Penelitian Kuantitatif. Alfabeta. Bandung.

Sugiyono. 2016. Metode Penelitian Pendidikan Pendekatan Kuantitatif, Kualitatif Dan $R \& D$. Alfabeta. Bandung.

Singarimbun, M dan Effendi. 1989. Metode dan Proses Penelitian. LP3ES. Jakarta. 